\title{
Life, Nonlife, and Karma
}

In this chapter, we introduce the Jain understanding of life as it exists in and interacts with the various aspects of the nonliving reality. Since the karmically produced, material body is considered to be nonliving and perishable, while life itself is eternal, understanding this interaction is essential for determining the principles for Jain bioethics. We first explore the foundations of Jain cosmology and metaphysics, after which we closely examine the doctrine of karma. We then outline the various classifications of living beings, as well as the Jain conceptions of birth, aging, death, rebirth, and liberation. We conclude the chapter by identifying four foundational principles when considering what exists according to the Jain view of reality.

\section{THE JAIN COSMOS}

The interactions between the living and nonliving reality all take place in the Jain cosmos (loka-ākāśa, "space with worlds"). The cosmos is understood to be uncreated and eternal, without temporal beginning or end. While it is deemed to be very large, its specific shape indicates that it has a finite size. Within their canonical texts, Jains imagined the cosmos as being narrow in the middle and wide at the top and bottom. ${ }^{1}$ As the Jain cosmological teachings became more complex, their depictions of the cosmos also became increasingly elaborate, and the cosmos commonly came to be rendered in the shape of a human being (loka-purusa), narrow at the waist, with legs standing wide apart and arms bent at the elbows, resting at the hips (see figure 1$)^{2}$

Even though they are highly technical, the Jain doctrines of the cosmos are importantly intertwined with the Jain soteriology, which is why they are well known and widely circulated not only among Jain mendicants but also in the lay circles. ${ }^{3}$ In fact, reflecting on the nature of the cosmos is taken to be an important spiritual practice for all Jains. ${ }^{4}$ Since there is order in the cosmos, one can use the 


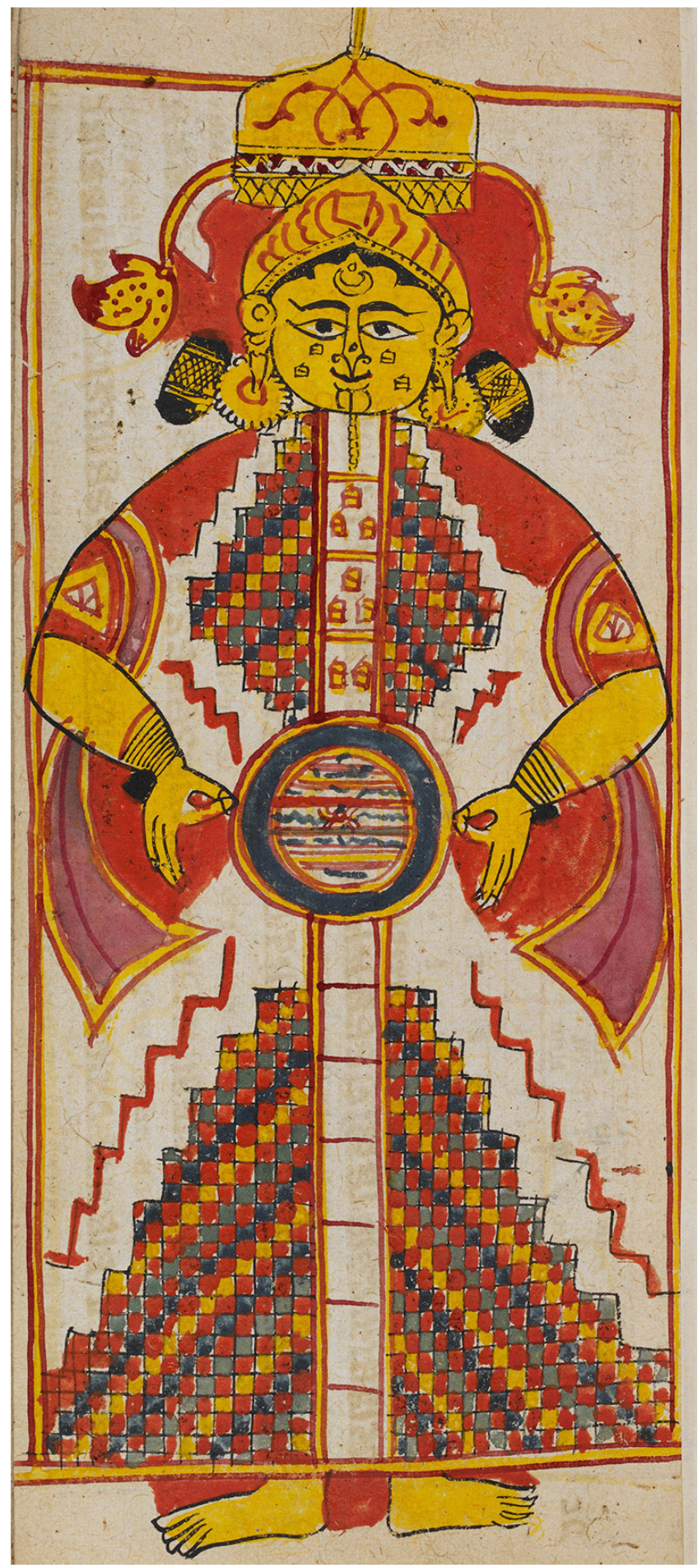

FIGURE 1.

Depiction of the Jain cosmos as a human being, from a seventeenthcentury manuscript of Śrīcandrasūri's Saṃrahaṇi-ratna (Pkt. Samghayanarayaṇa), composed in Prakrit with a Gujarati commentary. This twelfthcentury text explains the structure of the cosmos and the living beings that occupy it, and the manuscript contains a large number of rich visual representations of the various aspects of the cosmos. Credit: British Library. 
knowledge about its nature to anticipate future situations as well as carve out a life course in accordance with what one deems valuable, and it is only by understanding the structure and processes of the cosmos that one can hope to take the right steps on the path to liberation (see chapter 3 ).

The Jain cosmos is said to be enclosed in an infinitely vast and empty acosmic space (aloka-ākāśa) but is itself completely filled with living and nonliving entities (US 36.2). Jains not only recognize a great diversity of living entities, but they also have a remarkably expansive understanding of what "counts" as life and is therefore considered inviolable. Different embodied life-forms exist in specific parts of the cosmos, which means that some of them are likely to encounter and interact with one another while others are not.

The upper body of the cosmic human being, shaped somewhat like an inverted pyramid, is the upper world ( $\bar{r}$ dhva-loka) that consists of a number of heavenly realms and is populated by heavenly beings or gods (deva). The lower, pyramidshaped part of the cosmic human is the lower world (adho-loka), which is the abode of various hell-beings (näraka). ${ }^{5}$ The world in between is the middle world (madhya-loka), the smallest one of the three. It is often visually represented as a circle in the navel part of the cosmic being, even though it is described as a horizontally positioned flat disk that contains a central island called the Jambū-dvipa (Island of the Rose-Apple Tree). This island is surrounded by numerous concentric oceans and islands, and while animals (tiryañc, "going horizontally") can exist throughout the whole of the middle world, human beings (manusya) occupy only two-and-a-half innermost islands (TS 3.7-9, TS $^{\text {Sv }} 3.14^{6}$ ).

This small living space highlights how scarce the human presence in the cosmos is, underlining the exceptionality of the human condition, which we will return to below. ${ }^{7}$ While the abode of human beings is by far the most limited, the living regions of animals, hell-beings, and heavenly beings are also restricted to a central, cylindrically shaped area called the mobile channel (trasa-nāẹ $\bar{i}$ ), which reaches from the lowest hell to the highest heaven. In contrast to this, certain types of living beings can exist in all parts of the cosmos, including beyond the central cylinder. These are plant- (vanaspati-kāyika), earth- (prthvi-kāyika), water- (āpo$k \bar{a} y i k a)$, fire- (tejo-kāyika), and air-bodied beings (vāyu-kāyika), which are commonly classified under the fourth category together with animals.

Some living beings in the cosmos are easily recognizable, while others occupy subtle and elusive bodily forms. In accordance with this, the Ācāränga-sütra (Pkt. Āyāramga-sutta), ${ }^{8}$ a Śvetāmbara canonical text, describes Mahāvīra’s practice of carefully examining the surroundings in order to prevent causing harm to any, even minute, life-forms whose animacy may not be apparent, such as mold (panaka), seeds (bija), (minute) plants (harita), ${ }^{9}$ as well as earth-, water-, fire-, and air-bodied beings. The text states that Māhāvīra's realization of their being alive came after observing them closely, and consequently, he avoided injuring them (ĀS 1.8.1.11-12). As we will discuss in chapter 3, this general instruction to 
pay attention to the minutest of living beings gradually evolved into detailed rules for mendicants, including exercising great care when performing daily activities (samiti) as well as a regular inspection of clothes and implements for any small life-forms.

The ethical aspiration not to harm the abundant life that exists in the cosmos represents one of the core endeavors constituting the Jain path to liberation. As will be explained in detail in chapter 3, Jain practitioners realized that violence caused to other living beings is in fact violence caused to oneself, preventing one from attaining the ultimate goal of the religious path. This not only resulted in restrictive practical rules for mendicants and laity, such as those mentioned above, but also contributed to the development of complex metaphysical doctrines (cf. Johnson 2014, 135). Jains endeavored to delineate the boundary between life and nonlife with meticulous care, provide detailed taxonomies of life-forms, and thoroughly understand how they are born, live, and die.

\section{THE “REALS”}

Jain texts often put forward the distinction between the living and the nonliving in the context of the broader outlines and considerations of that which exists or is real. A common method of organizing reality is to list the so-called "reals" (tattva), or fundamental categories, of which texts frequently enumerate seven or nine. They include (1) living entities (jīva); (2) nonliving entities (ajīva); (3-6) the influx (āsrava), bondage (bandha), stoppage (samvvara), and removal (nirjarā) of karma; (7) liberation from the karmic cycles of rebirth (moksa); and sometimes (8-9) nonmeritorious types (pāpa-prakrti) and meritorious types (punya-prakrti) of karma. ${ }^{10}$ While the Śvetāmbara canonical texts tend to record nine "reals," commonly mentioned reference for the list of "reals" is the Tattvärtha-sütra 1.4 in which Umāsvāti (c. fourth century CE) lists seven of them. His Digambara commentator Pūjyāpada (sixth century) explains that the nonmeritorious and meritorious types of karma are already implied in karmic influx and bondage (SSi $1.4 \$ 19) .{ }^{12}$ John Cort suggests that the exclusion or inclusion of the last two "reals" may relate to disagreements with regard to the relative moral value of the meritorious types of karma. He writes:

If punya and pāp are considered only within the framework of karmic bondage, then they are viewed in a wholly negative light. If they are considered as universal principles independent of their classification under bondage, then action that is karmically binding yet morally valuable is not viewed so negatively. In other words, an ontology of just seven tattvas accords value only to the moksa-märg goal of liberation from the world by eliminating all karmic bondage, whereas an ontology of nine tattvas allows room for positive valuation of action within the world by distinguishing among forms of karmic bondage, and therefore accords some importance to wellbeing. (2001a, 192) 
We will be returning to this distinction between action that is aimed at the ultimate goal of liberation and action that is directed at well-being in the next chapters of the book.

While the list of "reals" is primarily concerned with metaphysical principles and processes, it came to be associated with epistemological, ethical, practical, and soteriological considerations by connecting them with the triple path to liberation or the so-called "Three Jewels" (ratna-traya): right worldview (samyag-darśana), right knowledge (samyag-jñāna), and right conduct (samyak-cāritra) (cf. Ohira 1982, 56). ${ }^{13}$ From the late canonical period onward, the "reals" were defined as the content of the right worldview (Ohira 1982, 56).${ }^{14}$ Right knowledge came to include various means of attaining valid knowledge about the "reals." Right conduct, to which is sometimes added asceticism (tapas), ${ }^{15}$ relates to the ethical and practical aspects of the path that are aligned with the first two "jewels," which we will discuss in detail in chapter 3 .

Connected with the triple path to liberation, the list of "reals" indicates that in philosophical and practical respects, living and nonliving entities interact with one another and remain intractably bound together in the world of embodied living beings. The rest of the present chapter will explore the complexities of this relationship, particularly concerning the living entities and karma.

\section{LIVING AND NONLIVING ENTITIES}

The first two "reals" represent a basic categorization of everything that exists, recognizing that some things that exist are alive while others are not. ${ }^{16}$ The "reals" that are listed after this initial statement of fundamental ontological dualism represent various aspects of the operation of nonliving karma, including its complete elimination and the jiva's consequent attainment of liberation. Knowledge of metaphysics is therefore placed at the very foundation of the soteriological path. ${ }^{17}$

\section{Structure and Dynamics of Existents}

Jains consider everything that exists to be expressed through substances (dravya) and their qualifiers. ${ }^{18}$ They posit a multiplicity of eternal substances, five kinds of which are considered nonliving and one kind of which is living. The living kind of substance is called jiv $a$ or ätman, often translated as the self, living substance, living entity, or soul. ${ }^{19}$ Nonliving kinds of substances include matter (pudgala), ${ }^{20}$ medium of motion (dharma), medium of rest (adharma), space (ākāśa), and, according to some Jain authors, time $(k \bar{a} l a) .{ }^{21}$ Among these six living and nonliving kinds of substances, Jains regard space, which is single in number, as the only one that is infinite. The media of motion and rest are two single substances that enable entities to move and come to a stop, and their size, which is vast yet finite, determines the boundary between the above-mentioned finite cosmic part 
of space and the infinite acosmic part that stretches beyond it. The other substances, including an infinite number of jivvas, exist only inside the boundary of the cosmic space.

All substances, no matter what type, have the same basic structure. ${ }^{22}$ They all possesses essential qualities (guna), some of which are unique to each kind of substance and represent criteria by which substances can be differentiated from one another. All the qualities undergo continuous, momentary, beginningless, and endless modifications in the form of a series of modes (paryāya).

A simple example of this may be to consider the material substance of a leaf changing in its quality of color from green to red to yellow to brown, which represent its modes. Like the leaf that persists through its various changes, all entities in the Jain conception of reality are understood to be permanent in one aspect and changing in another. They are permanent when considered from the perspective of the substance and its qualities, and they are changing when considered from the perspective of the modes. This emphasis on taking into account a multiplicity of perspectives when exploring an object is present already in the canonical period, ${ }^{23}$ and it gradually develops into sophisticated metaphysical, epistemologi$\mathrm{cal}$, and logical doctrines of non-one-sidedness (anekānta-vāda). These include (1) niksepa-vāda and naya-vāda, or the doctrines of various standpoints (nikșepa) ${ }^{24}$ and viewpoints (naya) from which an object can be considered; and (2) syād$v \bar{a} d a,{ }^{25}$ or the doctrine of conditional assertion, which expresses that something exists in a specific way "in some respect" (syāt), and is formalized in the list of seven kinds of predication (sapta-bhaingī) that can be made about an object (Balcerowicz 2001; Balcerowicz 2003; Jaini 2001/1979, 90-97; Koller 2000; Long 2009, 141-54; Matilal 1981). ${ }^{26}$

With these doctrines, Jains carved out a space for themselves in the South Asian philosophical arena. The non-one-sided approach allowed them to illuminate the competing doctrines that did not follow their methodology as one-sided (ekānta) and only partially true, and to distinguish their own doctrines from them (Bajželj 2020).

In line with this, it is important to note that the non-one-sided approach traditionally does not represent a form of philosophical pluralism or relativism, since it is clear that for Jains their own view of reality is absolutely, and not only relatively, true. As we will see below, a perfectly developed comprehension of reality involves a complete capturing of all existing objects in their infinite complexity, which represents absolute truth that transcends all partial perspectives. Truth is relative and confined to its specific contextual parameters only for a limited cognizer, and taking a limited truth to be the whole truth is what constitutes a wrong view (mithya-drști). In line with this, the doctrines of non-one-sidedness do not correspond to intellectual nonviolence, as some have suggested. Jain texts unambiguously promote their doctrines as the only truth and usually do not spare their opponents when engaging with them, even while recognizing that they too 
put forth comprehensive philosophical systems (Cort 2000; Johnson 1995b; cf. Barbato 2017).

\section{The Relationship between Living and Nonliving Entities}

Jains deem all jivvas that we encounter in our lives to be embodied, and it in the embodied condition that their non-one-sidedness is commonly referred to. ${ }^{27}$ Each jìva, which is a living substance, inhabits a body ( $k \bar{a} y a$ or śarira) that is a material and therefore nonliving substance. This means that embodied beings are understood to be living in some respect and nonliving in another.

What, then, is the mark by which life can be detected and distinguished from nonlife? In his Tattvārtha-sūtra, Umāsvāti describes the active use (upayoga) of consciousness as the defining characteristic of the jivva (TS 2.8; Soni 2007). In fact, Jains consider consciousness to be an essential and inalienable quality of all jīvas, which means that no jīva can ever lose conscious awareness no matter what its state or material form. In his Digambara commentary to the Tattvārthasūtra, Akalankka (eighth century) describes it as the beginningless inherent nature (svabhāva) of the self (ätman), in the same way that gold has its inherent nature that persists through its various modifications into a bracelet, a ring, or some other object (TVā 2.8.1).

Consciousness operates in two aspects: (1) perception (darśana) and (2) knowledge (jūanna). The two other essential qualities that are unique to a jīva are (3) energy (virrya) and (4) bliss (sukha), with the former animating different levels of perception and knowledge and the latter representing the degree to which a jiva's desire is self-contained (svabhāva-sthita) rather than grasping at external objects (Jaini 2001/1979, 104-5). This basic structure indicates that all jivas are essentially equal in their qualities of and capacity for perception/knowledge, energy, and bliss, varying only in the modal aspect of each quality. ${ }^{28}$ These inherent qualities of jìvas, according to Jainism, therefore define life and distinguish it from all nonlife, including the body.

As a way of highlighting the jīva's complex relation to nonlife, Pūjyapāda instructively describes four different kinds of earth in his Sarvārtha-siddhi. The first kind is earth as nonliving material (prthivi $)$, which is devoid of consciousness. This is just matter and is not presently associated with a jivva. The second kind is earth as a body (prthivi-kīya) that has been abandoned by the jīva present in it, similar to the dead body of a human being. The third is earth as an embodied being (prthivi-kāyika), which is a jivva that has earth for its body and presently occupies it. The fourth is earth-jīva (prthivi-jivi), a jīva that has discarded its previous bodily form and is in transit toward a new earth body based on past karma (SSi $2.13 \$ 286)$.

The mention of these four types of earth is significant, because it means that not everything material that a Jain practitioner encounters is violable, but also that identifying what is violable can be challenging. The first two kinds of earth, 
earth as matter and discarded earth-body, are not conscious (acetana), not living, and, therefore, cannot be violated. The fourth kind, earth-jiva in transit, is also considered nonviolable, since it does not yet occupy a gross material body, ${ }^{29}$ the only form in which an immaterial entity can experience harm. Out of the four, only the third kind of earth, a jivva that presently occupies an earth body, is violable (Wiley 2002, 39-40). The case of these four types of earth is particularly suggestive, since it is much more difficult to differentiate between living and dead earth than, for example, between a living and a dead body of a human, insect, or flower. It draws attention to the fact that jivas in bodily forms that are difficult to distinguish from material forms that may not or no longer house a jivva can easily be unrecognizable as living beings, and are thus more vulnerable to violation.

\section{Inhabiting a Succession of Bodies}

In the case of jivas that are presently embodied, the duality between life and nonlife is also somewhat misleading because, even though essentially different from it, the jīva cannot really be separated from the body until the attainment of liberation. Pūjyapāda compares the relationship between a jīva and the body that it occupies to a mixture of silver and gold. Just as the two metals remain distinguished by their color, and so on, even though they are combined together, so can the jiva be differentiated from the body by its property of consciousness even when in bondage (bandha) (SSi 2.8\$271). Here, Pūjyapāda alludes to one of the central facets of the Jain doctrine, namely, that the occupation of bodies is an entrapment. This condition has no beginning and possibly no end, ${ }^{30}$ unless an individual rigorously adheres to an ascetic life of nonviolence, including the purification of bodily, verbal, and mental activities (described in greater detail in chapter 3 ). The continuity of the entrapment is considered to be uninterrupted, since upon death in one particular body, a jīva - as will be detailed below_almost instantaneously migrates to another body, and is enclosed by subtle bodily forms even during the migration. A jivva successively occupies a multiplicity of bodies, and even though particular embodiments form a continuum, they are all necessarily impermanent, because every occupied body-while real and significant in the journey of each jivva-is transitory in nature.

In his twelfth-century Triṣaṣtiśalākāpuruṣa-caritra, Hemacandra, a Śvetāmbara Jain mendicant leader and polymath, compares the migrations of jivvas between bodies to the experience of traveling, with bodies representing temporary stops for the travelers: "Not even the body is one's own. There is nothing but a halt in one place of those who have come here from different places, like that of birds in a tree. Then people go elsewhere to different places, like travelers who have slept in one place at night departing at dawn" (TC 2.1.61-62, trans. Johnson). Throughout their migrating journeys, jivvas are then merely borrowing bodies-places to temporarily inhabit. As indicated above, these bodies that the jiv vas occupy are of a wide variety, and the connection between a jiva and the specific body it inhabits 
is not arbitrary. Jain philosophy explains each particular embodiment through the doctrine of karma.

\section{THE CAUSE AND EFFECT OF KARMIC MATTER}

The complex and remarkably detailed Jain doctrine of karma far exceeds any popular notion of "what goes around comes around" determinism. ${ }^{31}$ It is essential for understanding how Jains view the bond between bodies and jīvas; the events of birth, life, and death; and the temporal, physical, and moral entanglements between living beings; as well as the motivations and goals of Jain ethics. As such, it is central for the exploration of Jain bioethics. Jains understand the process of migration from one birth to another to be driven and operated by karma that each jiva accumulates throughout its lives. This karmic deposit determines the nature of all of its embodied existences and defines other aspects of its bondage in the cycle of rebirths (samsāra). This means that knowledge about karmic processes provides insight into the intricate mechanism of the entrapment, one's specific circumstances in it, and the possible methods of transcending them.

\section{Karma as Material}

Among the religious traditions of India, Jainism is rare in understanding karma to be material. ${ }^{32}$ However, only a portion of matter is deemed to be karmic. The substance of matter exists throughout the entire cosmos, and its most basic units are indivisible particles (anu), which like jivvas also possess their own set of essential qualities. For particles, these qualities are color (varna), taste (rasa), smell (gandha), and touch (sparśa). The quality of touch constantly undergoes modal change in the different degrees of dryness (rükșatva) and viscosity (snigdhatva). The greater the degree to which particles differ in their quality of touch, the stronger the attraction between them. For example, a very dry and a very viscous particle will be drawn to each other, whereas two very dry particles will repel each other. This dynamic causes the material particles to continuously integrate and disintegrate, and results in the formation of numerous kinds of material compounds or aggregates (skandha) (TS 5.23-27, TS ${ }^{\text {Dig }} 5.33-36^{33}$ ). Some very subtle types of aggregates are capable of interacting with jivas, and in accordance with this, one of the Jain classifications divides them into two categories: (1) those that are karmically bondable (yogya), meaning being able to bind to the jivva; and (2) those that are not bondable (aprayogya) (PS 2.76). ${ }^{34}$

How does this interaction between material aggregates and jivas occur? It is the bodily, verbal, and mental activities of embodied jivvas themselves that trigger the matter to flow to them. Some of this matter is karmically bondable aggregates (Wiley 2003, 338-39). Pūjyapāda compares the channeling function (prañālikā) of the activities through which karma flows to a jiva to streams by means of which water flows into a lake (SSi 6.2\$612). ${ }^{35}$ However, as Umāsvāti states, it is passions 
(kașāya) that fasten these inflowing karmic aggregates to a jīva: "Because of the state of having passions (sakașāyatva), the jivva grasps the bondable (yogya) material substances (pudgala) of karma. This is bondage (bandha)" (TS ${ }^{\text {Dig }} 8.2 ;^{36}$ Schubring 2000/1962, 174). ${ }^{37}$

While earlier Jain texts place particular emphasis on the passions of aversion (dveșa) and attachment (rāga), ${ }^{38}$ the classification of passions gradually becomes more detailed and systematized, with anger (krodha) and pride (māna) listed as two kinds of aversion, and deceitfulness $(m \bar{a} y \bar{a})$ and greed (lobha) as two kinds of attachment, each having four subtypes in accordance with the degree of their intensity. ${ }^{39}$ If jīvas engage in bodily, verbal, and mental activities that are guided by any one or a combination of these passions, the attracted karma is firmly bound to them for a long time (sämparäyika), constituting the constricting bond between jīvas and matter and strengthening the bondage in samsära. ${ }^{40}$ Accordingly, the Daśavaikālika-sūtra ${ }^{41}$ describes the four passions as watering the roots (of the tree) of rebirth (punar-bhava) (DVS 8.39).

As will be explained in detail in chapter 3 , in the absence of passions, matter is drawn to a jiva but does not attach to it, producing short-term karmic bondage (ìryāpatha) (Jaini 2001/1979, 112-13; Schubring 2000/1962, 174). A passionless jīva, says Akalañka, is like a dry wall to which nothing sticks (TVā 6.4.7). Indicating that passions, on the other hand, act like glue, Akalanka compares karma that gets attracted to a passion-driven jiva to dust attaching to a wet cloth, which also accentuates the idea that karma is a polluting agent (TVā 6.2.5; Glasenapp 1999/1925, 184-85). ${ }^{42}$ In this way, a jiv a surrounds itself, as Hemacandra states, "by self-made snares of karma, like a spider with webs made from its own saliva" (TC 2.1.53, trans. Johnson). Walther Schubring points out that matter is not yet karmic while being attracted to the jiv va. Only once it penetrates the jiv va does it attain karmic character. "All other matter," Schubring states, "pertains to the soul but externally" $(2000 / 1962,173){ }^{43}$

Jain philosophers mostly maintain that no one can affect another person's karma, which means that everybody is solely responsible for the karma they have accumulated (Jaini 2010b, 136-37). This, however, does not mean that practices contrary to this idea did not develop within Jainism, and Cort records a number of instances based on inscriptions, texts, rituals, and his fieldwork that demonstrate the presence of the idea of karmic transfer within the tradition. Common examples are donations of images, donations for manuscript copies, and temple constructions, accompanied by information about the persons for whose welfare they are intended. ${ }^{44}$ Even some mendicant leaders, such as Devendrasūri, the second leader of the Śvetāmbara Mūrtipūjaka Tapā Gaccha, ${ }^{45}$ and the great Tapā Gaccha philosopher Mahopādhyāya Yaśovijaya, are shown to have promoted these ideas, which indicates that they did not develop only in lay circles and in isolation from mendicancy. One of the examples that Cort mentions in support of his argument is the story of King Śrīpāla and his wife Mayaṇāsundarī, in which Mayaṇāsundarī 
uses the merit accumulated through worship ${ }^{46}$ to cure her husband and a community of seven hundred of leprosy by pouring water that she used for worship over them (2003). ${ }^{47}$ While the notion of karmic transfer was clearly not absent from the Jain tradition, the predominant methods of influencing one's own karma prescribed by the doctrine have been arduous practices of restraint and asceticism. These will be discussed in detail in chapter 3 .

\section{Kinds of Karma}

Bondable material aggregates that are ready to interact with a jivva exist in an undifferentiated state while still unattached, but once interaction with a jīva occurs, they modify into specific kinds of karma (Jaini 2001/1979, 112). ${ }^{48}$ Jain texts distinguish 148 kinds (uttara-prakrti) of karmic matter that bind jivvas, with their names indicating the sorts of effects they produce. Different types of karma are directly related to the types of activities that attracted karmic matter in the first place, reflecting both the type of activity (bodily, verbal, mental) and its nature (meritorious or nonmeritorious) (Jaini 2001/1979, 113, 115; Schubring 2000/1962, 292-93). ${ }^{49}$ Jain texts classify them into two main groups. The first group-called ghātiyadescribes four kinds of karma that are destructive of the four essential qualities of the jiva. The second group-called aghätiya-includes four kinds of karma that are nondestructive to the jiv va, but instead determine the kinds of embodiments the jivva will experience..$^{50}$ These two groups together represent the eight main kinds (mūla-prakrti) of karma, described in detail below (GKK 7-9). ${ }^{51}$

Destructive Karma. As indicated above, destructive types of karma are considered "destructive" because they weaken the operation of jivvas, preventing the total and potentially infinite manifestation of their essential qualities. They are divided in accordance with the quality of the jivva they impede: (1) perception-obscuring (darśana-āvaraṇiya), (2) knowledge-obscuring (jñāna-āvaran̄iya), (3) energyobstructing (vīrya-antarāya), and (4) bliss-defiling (mohanìya) ${ }^{52}$ types of karma (Glasenapp 1942/1915, 6-11, 18-19; Jaini 2001/1979, 117-23). We will address the relation between the qualities of the jīva and their respective destructive karmas in turn.

Perception- and knowledge-obscuring karmas inhibit the arising of omniscience or perfect knowledge (kevala-jĩāna) of every existing substance and all of its infinite modes, which is an innate capacity of jivas. ${ }^{53}$ This form of knowledge is a precondition for release from the cycle of rebirths, and the people who attain it are called kevalins, a category that includes the Jinas. The destructive karmas affect the changing modes of the quality of consciousness and consequently determine how "conscious" each living being is. While all living beings are equal from the perspective of possessing consciousness, since consciousness is not an alienable characteristic, as indicated above, they differ from the perspective of the degree of its modal manifestation. For example, depending on how much knowledge- and perception-obscuring karma is active, the quality of consciousness of some 
embodied beings, such as plants, is heavily impaired, while it is much more operative in some other living beings, such as humans or animals that possess a mind (see "Classification of Living Beings" below).

Like the quality of consciousness, the quality of energy cannot be completely terminated by karma. It can, however, be severely diminished by it, and it is the weakening of the energy-quality that is instrumental for karmic influx. Helmuth von Glasenapp explains that in its restricted condition, the energy-quality operates through material media in the form of the body, the organ of speech, and the mind, producing activities (yoga) that we mentioned above. These three kinds of activities bring about vibrations (parispanda) of the space-points of the jiva or the self (ätma-pradeśa).$^{54}$ As noted above, passions cause karma to bind, but it is these vibrations produced by the bodily, verbal, and mental activities of jivas that cause karmic influx in the first place (Glasenapp 1942/1915, 45; Jaini 2001/1979, 112; Wiley 2000a, 42; cf. Soni 2016). Furthermore, because the energy-quality powers perception and knowledge, these two qualities function less effectively when energy is obstructed by karma. In line with this, Wiley mentions that apart from impeding physical energy and willpower, the energy-obstructing karma inhibits mental powers and concentration (2012, 190). Energy-obstructing karma also hinders generosity to others, accepting gifts, and enjoyment of things that can be taken once (such as food or drink) ${ }^{55}$ or repeatedly (such as a dwelling or clothes) (Glasenapp 1942/1915, 18-19).

Unlike karma's partial impact upon the other three qualities, bliss is the only quality of jivas that can undergo true defilement (Jaini 2001/1979, 117). Jaini notes that this transformation (vibhāva-parināma) of the quality of bliss represents a proper change of state, similarly to the transformation of a liquid state into a solid state (2001a, 137). ${ }^{56}$ It is important to note that bliss is not a pleasant sensory or mental feeling, since both senses and the mind are material as will be discussed in detail below. Moreover, pleasant feelings are a product of nondestructive feeling-producing karma. Instead, in its pure manifestation bliss represents precisely independence from all the various material media of experience like all the other essential qualities, and refers to a state of self-contained desire that is not grasping at things "out there," as mentioned above (137). In contrast to this, bliss-defiling karmic matter results in delusion (moha) and passions (kașāya) ${ }^{57}$ It is accordingly divided into two types: (1) worldview-deluding (darśana-mohaniya) and conduct-deluding (cäritra-mohanìa). These factors enact a cycle of karmic capture wherein worldview-deluding karma hinders right worldview of the true nature of reality (samyag-darśana), which attracts more worldview-deluding karma, sustaining a wrong view of reality (mithyātva). Conduct-deluding karma results in nonobservance of right conduct (samyak-cāritra), which, in turn, attracts more conduct-deluding karma, leading to further damaging actions. Passions represent a key factor in karmic bondage, so removing the karma that produces them is essential on the path to liberation, as will be detailed in chapter 3 . 
According to the Jain doctrine of destructive karma, each embodied living being is, therefore, enlivened by a unique, authoritative jiva whose inherent qualities are always present and operational. These qualities are obscured to various degrees, but never permanently so. This means that a snail is similar to other living beings in that it houses a jiva; it is also radically singular since the jivva is characterized by, among other things, perpetually fluctuating degrees of perception, knowledge, energy, and bliss conditioned by the ongoing karmic dynamics. As will be demonstrated below, the levels to which the qualities of living beings are polluted by the destructive kinds of karma provide the basis for the Jain classification of living beings as well as their hierarchical categorization.

Nondestructive Karma. Whereas destructive karma affects the inherent qualities of jivas, nondestructive karma determines the characteristics of their embodiments. Nondestructive karma is also subdivided into four types: (1) name-determining karma (nāma-karman), ${ }^{58}$ (2) longevity-determining karma (āyu-karman), (3) status-determining karma (gotra-karman), ${ }^{59}$ and feeling-determining karma (vedanīya-karman) ${ }^{60}$ (Glasenapp 1942/1915, 8, 11-18; Jaini 2001/1979, 124-27) ${ }^{61}$ We will describe each of these types here.

Name-determining karma, which is subdivided into ninety-three different kinds, determines into which birth state (gati) a jivva will be born, as well as the subclass (jāti) of the birth state, and each jīva's particular body (śarìra) for every embodied existence. According to Jain texts, there are 8,400,000 possible birth states, ${ }^{62}$ which fall into four main groups that were mentioned above in the section on the cosmos: (1) humans; (2) heavenly beings; (3) hell-beings; and (4) a group of beings that includes animals, plants, and earth-bodied, water-bodied, fire-bodied, and air-bodied beings (SSi 8.23\$778; Glasenapp 1942/1915, 11). By determining the specific bodies that the jivvas occupy, name-determining karma defines their particular sense-faculties, the specific ways in which their bodily parts are formed, their mobility, and so forth.

Apart from the principal gross physical body (audārika-śarìra), which is unique to humans and living beings with one to five senses, name-determining karma generates other kinds of bodies as well. The luminous body (taijasa-śarira) contains fiery matter, and its function is to sustain the temperature of living beings and digest food for the gross physical body. ${ }^{63}$ The karmic body (kärmaṇa-śarīra) represents all the subtle karmic matter that adheres to jivas. Glasenapp highlights that this body "changes every moment, because new karman is continually assimilated by the soul and the already existing one is consumed" (1942/1915, 12; TVā 2.36.17). It is through this body, explains Akalanka, that all the other bodies are formed (TVā 2.36.12). There are an additional two bodies that may be formed, namely the transformational body (vaikriya-śarīra), which can perform various supernatural functions, ${ }^{64}$ and the translocational body (ähäraka-śarīra), which allows humans to travel to those places in the cosmos where Jinas teach, while leaving the 
gross physical body behind (PS 2.79; TS ${ }^{\text {Dig }} 2.36$; Glasenapp 1942/1915, 12). Of these various bodies, the gross physical body is the least subtle and the karmic body is the most subtle, with subtlety being related to the density of material units (TS ${ }^{\mathrm{Dig}}$ 2.37-39) $)^{65}$ (Glasenapp 1942/1915, 12; Schubring 2000/1962, 139; Tatia 2010, 287-88). Umāsvāti states that all living beings trapped in saṃsāra have the karmic and the luminous body ( $\mathrm{TS}^{\mathrm{Dig}} 2.42$ ). ${ }^{66}$ While most Jain authors agree that the connection between a jiva and its karmic and luminous bodies is beginningless, the fifthcentury Tattvārtha-bhäșya 2.43 mentions that some Jain thinkers viewed only the association between a jiv $a$ and its karmic body to be beginningless.

All four kinds of nondestructive karma can manifest either in a meritorious (punya) or a nonmeritorious ( $p \bar{a} p a$ ) form. Meritorious name-determining karmas will result in the formation of bodies of humans, heavenly beings, or highly complex animals that have a pleasant voice, gait, color, taste, touch, odor, and so on. Nonmeritorious name-determining karmas, on the other hand, will result in the formation of bodies of hell-beings and less complex animals, plants, and earth-, water-, air-, and fire-bodied beings that have an unpleasant voice (if they can utter voices), gait (if they can move), color, taste, touch, odor, and so on (Wiley 20ooa, $117-18)$.

Longevity-determining karma establishes the length of a jiva's embodied lives. A distinctive feature of longevity-determining karma is that it is bound only once in a given lifetime and is activated in the subsequent embodied existence. This is unlike other forms of karma that are continuously attracted and bound to the jiv va and can come to fruition in either the present life or one of the future ones (BhS 5.3\$214a; Wiley 2000a, 88; Wiley 2003, 337). In spite of this difference, āyu-karman is closely related to nama-karman, since embodied existences are restricted to specific life spans (TVā 3.27.3; Wiley 2003, 337). If àyu-karman determines that the next life will last a certain span of time, the jiv $a$ will have to be reborn in a bodily form that allows it. Accordingly, the longevity-determining karma has four subtypes, each relating to one of the four birth states (manusya-āyus, deva-āyus, nāraka-äyus, and tiryañca-āyus) (Glasenapp 1942/1915, 11; Wiley 2003, 340). Nevertheless, this karma does not determine the exact number of years an embodied being will live, but rather an overall "quantity of life." Glasenapp explains: "For as the quantity of water in a sponge is definite, but not the period in which it drains it, the quantum of life is also definite, but not the period in which it is used up" (1999/1925, 188; see Schubring 2000/1962, 185). ${ }^{67}$ This will be relevant for our discussion on shortening the life span through illness, injury, and other factors in chapter 7 .

Conversely, specific birth states define the types of ayu-karman that can be bound to the jivva. The ayy-karman of a human being, for instance, cannot be bound by a fire-bodied or air-bodied being (Jaini 2003, 4). While the justification for this limit is not absolutely clear, Wiley suggests that "it might be that firebodied beings and air-bodied beings are thought to cause more hims $\bar{a}$ [violence] 
than earth-bodied beings, water-bodied beings, and vegetable life because they can move quickly from place to place with no restriction or without assistance" (2000a, 72). Whatever the reason, this particular prohibition demonstrates the close link between nondestructive karmas associated with body and longevity.

Status-determining karma determines the family, environment, or status of embodied existences, with ucca-gotra-karman occasioning more favorable and nica-gotra-karman less favorable conditions (Jaini 2001/1979, 125; TS ${ }^{\text {Dig }} 8.12^{68}$ ). The two subtypes of status-determining karma cannot be bound and come to fruition at the same time (Wiley 1999, 114). As Wiley emphasizes, Jain texts define status in different ways, "including family lineage, conduct, or internal modifications of the soul" (124). She also points out that Śvetāmbara texts she is drawing from tend to emphasize family lineage and external manifestations of this karma, such as bodily strength, appearance, power associated with wealth, and performance of austerities. Digambara texts, on the other hand, place more emphasis on internal qualities, spiritual conduct, and even associating with virtuous people. Virtuous conduct is sometimes highlighted as binding ucca-gotra-karman (118-20). Some texts, further, clearly state that status-determining karma can change throughout one's life. Nìcagotra-karman can, for example, change to ucca-gotra-karman upon the assumption of total restraint, indicating progress in spiritual conduct (124; see chapter 3).

Vedaniya-karman, the fourth and last type of nondestructive karma, controls whether the embodied lives of jivvas have pleasant (sat) or unpleasant (asat) feelings (samvedana) about their environment, and thus conditions the degree of happiness or unhappiness inherent in any individual. Sātā-vedanìya-karman (also sad-vedya) gives rise to pleasant and asātā-vedanìya-karman (also asad-vedya) to unpleasant feelings (Wiley 2000a, 272). As vedaniya-karman is closely related to the experience of pain and illness, it will be discussed in more detail in the section on pain and sentiency below and in chapter $4 .{ }^{69}$

An important point to note is that no type of karmic matter, be it destructive or nondestructive, is bound to embodied jivvas eternally, but only for a limited duration (sthiti). After a period of dormancy ( $\bar{a} b \bar{a} d h \bar{a}-k \bar{a} l a)$, the attached karma rises (udaya) and comes to fruition with a particular degree of intensity (anubhàval anubhāga), and then breaks away (nirjarā) from the jivva (Wiley 2003, 339). Due to the fact that jivas are usually engaged in one or another kind of passion-informed activity, the karmic matter that has fallen off is ordinarily replaced by newly bound karma. ${ }^{70}$ Furthermore, the complex karmic mechanism expands beyond the present life. The karma that the jiva has accumulated in the past reaches fruition in the present, and the karma that it accumulates in the present will shape the possibilities of the future. The jiv $v a$, through its relation to karma, therefore maintains a thread between (a) the temporal past, present, and potential future; and thereby (b) between bodies occupied in the past, its current body, and rebirths yet to come; and (c) between the moral insights and actions of the past that determine its current understanding and conduct, and shape what capacities it might develop or diminish, in this lifetime or the next. 


\section{CLASSIFICATION OF LIVING BEINGS}

As noted above, Jain texts state that all living beings share certain basic qualities, such as consciousness. Despite this inherent similarity, living beings are also greatly diverse, mostly owing to their karmic bondage. Jains developed detailed taxonomies of the different varieties of life-forms, drawing from a wide range of criteria. Some of these taxonomies eventually came to be understood as hierarchical classifications that have been used to inform ethical decisions, as described in chapter 3. It suffices to say at present that early Jain mendicants were guided by ethical ideals that were fairly uncompromising, rooted in the equal value of all life-forms. In time, harm caused to the less complex living beings came to be understood as less karmically burdensome than harm caused to more complex living beings. This accommodation enabled the Jain lay community to live their lives as householders and still abide by the Jain ethical principles, only to a lesser degree than the mendicants for whom stringent ideals more or less remained the norm.

\section{Bound and Liberated Beings}

The broadest classification organizes living beings into those that are trapped in samsāra (samsārin) and those that are liberated (mukta) (TS 2.10; US 36.49). While liberated living beings, which always remain individual, are differentiated mainly with reference to their past lives (TS ${ }^{\text {Dig }} 10.9 .{ }^{71}$ US $36.50-55$ ), most classifications relate to nonliberated beings. These jivas are divided into "an infinity of possible birth-states," according to Jaini. "It is not only said that a given soul can be born into uncountable states of every type, but that indeed it already has done so and will carry on in virtually endless repetition of these experiences" (2001/1979, 108). Even though the states of embodiment that jivas migrate between are infinite in number, Jain texts find numerous ways of classifying them.

\section{Beings in the Four Birth States}

The most common classification of nonliberated embodied living beings is the already mentioned distinction between four birth states: $:^{72}$ (1) humans; (2) heavenly beings; (3) hell-beings; and (4) animals, plants, and earth-bodied, water-bodied, air-bodied, and fire-bodied beings. As this book deals with bioethics, we will predominantly focus on human beings, but where applicable to bioethical issues, we will also refer to living beings that we as humans encounter most frequently in our part of the cosmos. As indicated in the section on the cosmos, these are mainly beings belonging to the fourth category.

\section{Beings with Various Bodies}

We noted above that living beings in samsāra possess various bodies. One of them is the gross physical body, which describes the familiar "enfleshed" body of humans, animals, and plants, as well as the less familiar bodies of earth-, water-, air-, and fire-bodied beings. The gross physical body is the principal body 
(pradhāna-śarìra) of these beings, and it is the foundation on which their further classifications are primarily based. Along with plants, earth-, water-, air-, and fire-bodied beings are subdivided into two kinds: those with a subtle (sūkșma) body and those with a gross (bādara) body. Whereas the latter are restricted to living in the middle world, the former can occupy any part of the cosmos (GJK 184). ${ }^{73}$ Subtle-bodied beings are imperceptible, both when they exist individually and when collected into groups, and they can pass through matter. They do not obstruct, violate, or kill other forms of life, nor can they be obstructed, violated, or killed by them. ${ }^{74}$ This means that they always die naturally when their longevitydetermining karma runs its course. Drawing from Devendrasūri's Karmagrantha (thirteenth century), Wiley points out that individual gross bodies of earth-, water-, air-, and fire-bodied beings are also imperceptible, even though they are described as "gross." They become visible only in larger collections (Wiley 2000a, 120).

The Uttarädhyayana-sūtra ${ }^{75}$ helpfully lists the different kinds of these subtle and gross embodied lives, revealing an astounding variety of matter that may be concealing life apart from the more apparent living forms. Highlighting that these lists do not have merely a taxonomic purpose, the text says that a mendicant has to know the division of living and nonliving things (jivva-ajiva-vibhakti) in order to practice restraint (samyama) (US 36.1 ). As few contemporary Jain studies scholars address the great details provided in Jain taxonomy, it is worth outlining some brief examples to demonstrate the rich observation of (even minute) life-forms upon which Jain ethics is based. Whereas subtle bodies are identical in the case of each one of the groups of living beings that possess them, their gross bodies vary a great deal. This is true even for earth-, water-, fire-, and air-bodied beings. Gross earth-bodied beings, for instance, are divided into two categories: smooth (ślakṣna) and rough (khara), with the former having seven and the latter thirtysix subcategories. Smooth gross earth-bodied beings include black, blue, red, yellow, white, pale dust, and clay. Rough gross earth-bodied beings include, among others, earth (i.e., soil), gravel, sand, stones, rocks, rock-salt, iron, copper, tin, lead, silver, gold, diamond, orpiment, vermilion, realgar, antimony, coral, hyacinth, natron, crystal, emerald, sapphire, red chalk, sulfur, and lapis lazuli (US 36.71-77). The life duration of earth-bodied beings, both subtle and gross, ranges from less than a muhürta (forty-eight minutes) ${ }^{76}$ to twenty-two thousand years (US 36.81 ). Gross water-bodied beings include pure water, dew, fog, and ice. Water-bodied beings, subtle and gross, live anywhere between less than a muhürta and seven thousand years (US $36.85-88$ ). Gross fire-bodied beings include, among others, coal, burning chaff, fire, flame of fire, meteors, and lightning. Life durations of subtle and gross fire-bodied beings range from less than one muhürta to three days (US 109-113). Gross wind-bodied beings include squalls, whirlwinds, thick winds, high winds, and low winds, as well as hurricanes, and so on. Subtle and gross wind-bodied beings can live from less than one muhürta to three thousand years (US 36.118-22). The Uttarādhyayana-sūtra adds that there are, further, thousands of varieties of 
all these living beings, based on their color, smell, taste, touch, figure, and place (US 36.84, 36.92, 36.117, 36.126). ${ }^{77}$ This holds also for the other categories of embodied life.

\section{Individual or Communal Beings}

Another important criterion of classification is whether living beings live as individual bodies (pratyeka-śarīra) or communal bodies (sādhārana-śarìra; sāmānya-śarìra) (GJK 185). The Uttarādhyayana-sūtra states that plants that lead individual lives include trees, shrubby plants (where many stalks spring from the same root or bulb), shrubs (where twigs or stems spring from the same root or bulb), big plants such as lotuses, creeping plants such as gourds, grasses, palms, plants with knotty stems or stalks such as sugarcane, mushrooms, water plants, annual plants such as rice, and herbs. On the other hand, communal forms of plant life have more than one jivva occupying a single physical body, such as elephant foot yam, radish, ginger, onion, garlic, plantain-tree, red waterlily, turmeric, and many others (US 36.95-100).

Nigodas and Their Hosts. According to the Śvetanmbaras, the communal-bodied plants listed in the Uttarädhyayana-sütra are plants that act as hosts (pratișthal sapratiștha) to a minute kind of plant life called a nigoda. Jaini describes nigodas as being located at the very bottom of their birth category, "hence comprising the lowest form of life" (2001/1979, 109). Nigodas are themselves a communal type of plant life, with an infinite number of nigoda-jīvas functioning in a single coordinated nigoda body or cluster (golaka) (Jaini 201ob, 127). The Gommatasārajìva-kānda (ninth century) states that nigodas take nourishment, breathe, die, and are born together in the same body, at the same time (GJK 191-93). Even though the plants whose bodies they occupy may live a long time, the existence of nigodas is the briefest among all living beings.

Nigodas are divided into those that contain jīvas who have fallen to the state of nigoda from one of the higher birth states (Dig. itara-nigoda; Śv. vyāvahärika), ${ }^{78}$ and those who have always been born only into the birth state of a nigoda (Dig. nitya-nigoda; Śv. avyāvahārika) ${ }^{79}$ (GJK 197; Jaini 2010b, 127-28). Jaini points out that the category of the nitya-nigoda is how Jains have dealt with the problem of potentially exhausting the number of living beings trapped in samsāra due to their constant attainments of liberation. If living beings continue getting liberated, will the cycle of rebirths eventually run out of embodied lives? ${ }^{80}$

The Jainas deal with this problem by means of the nitya-nigoda. These beings are, unlike those of any other category, said to be infinite (anantānanta) in number, and thus to provide an inexhaustible reservoir of souls; as we might suspect, the rate at which members of the nitya-nigoda class leave their dismal condition and enter higher states for the first time is either equal to or greater than that at which human beings in various parts of the universe attain siddha-hood [i.e., liberation]. (2010b, 128) 
Nitya-nigodas can be reborn into any of the higher birth states. The Śvetāmbaras believe that Marudevī, the mother of R̦̣abha, the first Jina of our time, was a nityanigoda before her life as Marudevī in which she attained liberation as the first person to do so in the current cycle of time (Jaini 2003) ${ }^{81}$

According to the Śvetāmbaras, communal-bodied plants that function as hosts contain innumerable nigoda bodies and, thus, infinities of nigoda-jīvas. They maintain that plants that are listed as having individual bodies cannot act as hosts (apratiștha) to nigodas. The Digambaras dispute this claim, asserting that only nigoda-jivas possess a communal body. All the other plants have a single body only, but they are divided into those that can and those that cannot host nigodas (GJK 186). Host plants are classified as ananta-kāyikas, that is, those with bodies that hold an infinite number of jīvas. The difference between the Śvetāmbara and the Digambara understanding of the relationship between nigodas and their hosts is merely in classification, but for both, defining certain plants as hosts has an ethical significance. In karmic terms, destroying a plant that acts as a host has a much higher karmic cost than destroying a plant that does not (as further discussed in chapters 3 and 6). It should be pointed out that similarly to earthbodied, water-bodied, fire-bodied, and air-bodied beings, nigodas are also categorized into those with a gross and those with a subtle body; only the gross-bodied nigodas can be violated. As in the case of the others, the subtle-bodied nigodas can exist anywhere in the cosmos, whereas the gross-bodied nigodas exist in specific locations that are the bodies of other plants. Harming a plant that is a host, therefore, harms not only the host plant itself but the gross-bodied nigodas within it as well (Wiley 2000a, 122-24). This led Jains to avoid using host plants for dietary and medical purposes (see chapters 3 and 6). Importantly, Jaini notes that nigodas inhabit not only other plant-bodied beings, but also the flesh of animals and humans, where they "tend to become especially concentrated" (Jaini 2010b, 127; Jaini 2001/1979, 109). ${ }^{82}$ In line with this, cutting into flesh could be considered a violent action, even if for the sake of healing, an ethical limit that has implications for medical treatment and bioethics.

\section{Pain and Sentiency}

Jain texts demonstrate a deep awareness of the fact that the type of body that a living being possesses affects its experience in the world. A central hinge in Jain taxonomy in relation to bioethics is living beings' experience of pain. There is a recognition of the universal experience of pain and, thus, of a basic similarity of all forms of life as a motivation for refraining from causing harm to other beings (Vallely 2020). Already the earliest extant texts state that all living beings are the same in the sense that they want to live (priya-āyus) rather than be killed (apriya-vadha) as well as experience pleasure (sukha-svāda) rather than pain (duhkha-pratikūla) (ĀS 1.2.3.4).

As noted above, the type of karma that produces the feeling of pain is asātāvedaniya-karman, one type of nondestructive karma. ${ }^{83}$ Jaini emphasizes that 
feelings of pleasure and pain that are produced by vedaniya-karman accompany living beings throughout their lives. As long as jiv vas are embodied, they are "never free from pleasant and unpleasant feelings" (Jaini 2001a, 135; see also Wiley 2000a, 272). In fact, the state of liberation from karma, he explains, is not described as characterized only by the perfect manifestation of the jiv $a$ 's four essential qualities, but is also characterized by one specific "negative" quality called the avyābādha, which represents the "absence of restlessness or hurt." "In the notion of avyābādha," Jaini points out, "the Jainas seem to be emphasizing ... that the restlessness associated with the presence of feeling - even pleasant feeling - is at some level alien and painful to man [sic]" $(2001,136)$. In line with this, he points out delusion (moha) resulting from deluding karma, which transforms the quality of bliss-as a central factor of all of our experience of pain and suffering, comparable to the Buddhist concept of samskāra-duḥkhatā.

Like the latter it represents the a priori condition for all our ordinary experience, and, hence, for our experience of pleasure and pain. It stands, then, in opposition, not to pleasure as we ordinarily understand it, but to an absolute state of bliss, which is realized precisely in the absence of both pleasure and pain.... In this sense moha might be called a metaphysical kind of suffering - the instability and internal contradiction of a being whose actual state is a denial of his [sic] true nature. (2001, 137-38)

Living beings experience ordinary pain through their bodies, but not all of the five bodies that we discussed above allow their occupants to feel pain. The transformational and gross physical bodies both permit the experience of pain, while the karmic and fiery bodies do not (TVā 2.44; Wiley 2000a, 158). The transformational body, for example, allows the great suffering of hell-beings, and the gross physical body enables living beings to feel pain through the senses (indriya) and/or the mind (manas). Since the operation of the senses and the mind is driven by consciousness, the degree to which consciousness is karmically obstructed affects the complexity of living beings' sensory and mental capacities and, consequently, their experience of pain. It is important to note that sense cognition has two aspects: (1) the sense organ (dravya-indriya), as the physical aspect; and (2) the sense faculty (bhāva-indriya), as the internal aspect (TS 2.16-2.18). ${ }^{84}$ Nathmal Tatia explains them as "senses as clusters of matter" and "senses as modes of the soul" (2011, 43), a distinction we will revisit in chapter 5 in relation to embryology.

One-Sensed Beings. All beings that occupy a gross physical body according to Jainism possess at least one sense (eka-indriya), that is, the sense of touch (sparśana), and living beings that possess this single sense are considered the least complex forms of life. These are plants and earth-, water-, fire-, and air-bodied beings (TS ${ }^{\text {Dig }}$ 2.22). However, despite a severely obstructed quality of consciousness and a single sense of touch through which they come into contact with the world, Jain texts maintain that they still experience pain. The Bhagavatī-sütra states that all of them experience pain (vedanā) in the same way, indeterminately (anirdhārita), since 
they do not possess reflective awareness (asamjñ $i-b h \bar{u} t a){ }^{85}(\mathrm{BhS} 1.2 \$ 39 \mathrm{a}){ }^{86}$ It seems that it is in line with this that the Bhagavatī-sütra, further, compares the pain of an earth-bodied being to that of an "old decrepit man whom a young strong man gives a blow on the head" (BhS 19.3\$766b, Deleu 1996/1970, 250). The same holds for other one-sensed beings. While these beings experience pain differently from more complex living beings like humans, and are not able to be aware of it in a reflective manner, they nevertheless experience it, and comparing them to an elderly person highlights their frailty. Furthermore, one-sensed beings are not devoid of agency, and are stated as being capable of performing harmful activities and attracting karma like all other embodied lives (BhS 9.34\$491b; SKS 2.4.9-10).

Two- to Five-Sensed Beings. As indicated above, the greater the number of senses that living beings experience the world with, the greater their complexity. There are five senses in total: the already mentioned sense of touch, along with the senses of taste (rasana), smell (ghrāna), sight (cakṣus), and hearing (śrotra). Two-sensed beings include animals such as worms, conch shells, pearl mussels, snails, and leeches. They possess the senses of touch and taste (TBh 2.24). "The ability to taste indicates that these beings have a mouth," says Wiley, "through which they consume 'morsel food' (kavala-ähära) and by means of which they produce sounds (i.e., they have the ability of 'speech')" (2000a, 126). Three-sensed animals experience the world through the senses of touch, taste, and smell; this group includes ants, bugs, fleas, lice, weevils, centipedes, springtails, and termites. Four-sensed animals, which have an additional sense faculty of sight, include bees, flies, gnats, mosquitos, scorpions, spiders, butterflies, and moths. Five-sensed beings, which in addition have the sense of hearing, include human beings and animals such as fish, snakes, birds, and quadrupeds, as well as heavenly beings and hell-beings (TBh 2.24). Living beings are further divided into those that have a mind (samanaska) and can, therefore, reflect on and discriminate between merit and demerit ${ }^{87}$-and those that do not have a mind (amanaska) (TS 2.11, TS $^{\text {Dig }} 2.24^{88}$ ). Hell-beings, heavenly beings, human beings born from a womb, and some five-sensed animals born from a womb belong to the group that have a mind (TBh 2.25), as discussed below in a section on birth in a womb. As in the case of sense cognition, the mind has two aspects: (1) the organ, which is the physical aspect (dravya) ("clusters of matter"); and (2) the faculty (bhāva), which is the internal aspect ("modes of the jiva"). Despite these many differences, all living beings that have two or more senses have an individual, gross body that they experience the world around them with (Wiley 2000a, 126).

\section{Mobility and Immobility}

The distinction between cognitive abilities of living beings serves as a helpful foundation for another classification that groups them into those that can move (trasa) and those that cannot (sthāvara). Digambaras and Śvetāmbaras agree that all living 
beings that have two or more senses are mobile. The Digambaras designate all onesensed living beings as immobile (TS ${ }^{\text {Dig }} 2.13-14$; TVã 2.12.5), which means that, as stated by Tatia, "the automatic movement for the maintenance of life does not qualify a being as 'mobile" (2010, 42). Akalanka, further, indicates that despite not being able to move, living beings in the womb (garbha) still count as mobile beings (TVā 2.12.2). In fact, he says, mobility and immobility do not really depend on whether a living being is in motion or stationary; it rather relates entirely to the arising of particular karmas that determine mobility and immobility (TVā 2.12.5). These are trasa-nāma-karman and sthāvara-nāma-karman, respectively.

In contrast to the Digambaras, the Śvetāmbaras classify air-bodied and firebodied beings as mobile, along with all living beings that possess two or more senses $\left(T^{\text {Sv }}\right.$ 2.13-14). The Tattvārtha-tīka (ninth century) complicates the Śvetāmbara position on the status of air-bodied and fire-bodied beings by stating that-even though they move-they are not capable of moving voluntarily, which distinguishes them from the rest of the mobile beings (TT 2.14; see also Tatia 2010, 42). Pandit Sukhlalji indicates that while fire-bodied and air-bodied beings are characterized by the manifestation of the sthāvara-näma-karman like all the other one-sensed beings, they are mobile in a figurative sense because their motion is like that of mobile beings (Sanghvi 2000/1974, 87). In line with this, Wiley points out that, despite the difference in classification, "Śvetāmbaras and Digambaras agree that the bodies of fire-bodied and air-bodied beings are formed through the operation of sthāvara nāma karma" (2000a, 125). The prevailing criterion for classification seems to be the underlying karma for the Digambaras and the manifested motion for the Śvetāmbaras.

\section{Ability to Develop a Body's Capacity}

Another important classification divides living beings into those that are capable or incapable of completely developing their main physical body. This relates to, as Glasenapp explains, the "complete development of the organs (karana) and capacities (labdhi) of nourishment, of the body, of the senses, of breathing, of speech, and of thought" $(1942 / 1915,17)$, which will be discussed in more detail later in the chapter. The ability to attain complete development is decided by the arising of a specific kind of nāma-karman, called paryāpta-nāma-karman; its opposite is aparyāpta-nāma-karman (17-18). Beings that experience the arising of the latter pass away very soon after their birth ${ }^{89}$ (a trait we will revisit in regard to reproductive ethics in chapter 5). On the other hand, Wiley explains, "if paryāpta nāma karma comes into rise, then all of the capacities appropriate for a specific type of being will develop to completion, and death will not take place until this process is finished" (2000a, 129). Based on their cognitive capacities, subtlety, and ability to fully develop, the Gommatasāra-jīva-kānda lists fourteen classes of living beings (jīva-samāsa): (1) subtle one-sensed beings; (2) gross one-sensed beings; (3-5) two-sensed, three-sensed, and four-sensed beings; (6) beings without a mind; 
(7) beings with a mind; with each of them (8-14) either having a capacity for full development or not (GJK 72).

As noted, the meticulous taxonomies that we have discussed serve a better understanding of what in the world is violable and what is not. Furthermore, the diversity of life gradually came to function as a foundation for drawing hierarchical distinctions between living beings. This enabled the thriving of the lay community, who were permitted to harm one-sensed beings (see chapters 3 and 6).

\section{TRANSITIONS FROM BIRTH TO LIBERATION}

We conclude this chapter by describing various aspects of the different stages of existence, including birth categories, vitalities, capacities, and instincts of life; phases of aging; causes of death; the mechanisms of rebirth; and characteristics of liberation. This background demonstrates the comprehensive, and often technical, nature of Jain philosophy as it informs the ethical applications we will explore in part 2 of this book.

\section{Birth Categories}

Jains do not understand the processes of conception, growth of the body, and birth to be defined solely by material factors. All of them are determined by the arising of specific kinds of name-determining karma that have been accumulated as a result of various past activities performed by the embodied immaterial jivva. Since these activities vary greatly, the types of accumulated karma and their effects do as well. This means that living beings differ in how they are conceived, in how they grow, and in how they are born. Embodied life-forms are understood to be born (janma) in three different ways: (1) by agglutination or coagulation (sammürcchana/sammürchima), (2) by the womb (garbha), or (3) by descent (upapāda) (GJK 83; TS ${ }^{\text {Dig }} 2.31^{90}$ ). Heavenly beings and hell-beings are born by descent, meaning that they appear without having any need for a mother and a father (Jaini 2001/1979, 110), "with lightning-like suddenness without any material basis" (Schubring 2000/1962, 139; GJK 84). Living beings born by agglutination, which refers to matter joining together to form the jīva's body, include some fivesensed animals and humans, and all beings with fewer than five senses. Wiley describes birth by agglutination in the following way: "When the soul arrives at the place of birth, which contains matter suitable for forming the gross physical body (audārika-śarìra), it begins to assimilate matter present there, which can be living, nonliving, or both" (Wiley 2000a, 134).

The rare class of human beings who are born through agglutination potentially has some bearing on bioethical calculations in Jainism (SthS 6.20). The birth of these agglutinated humans is not attributed to sexual reproduction between a mother and father (Wiley 2000a, 136). Rather, as Tatia explains, they "originate in human excreta such as faeces, urine, sputum, mucus, vomit, bile, pus, blood, 
semen, etc." (2010, 54). Citing a passage from the Prajñāpanā-sūtra, ${ }^{11}$ Wiley writes that these humans can be found "in matter that has been made damp with semen before it has dried, in a corpse, in the union of males and females, and in sewers or holes where bodily wastes are deposited" (2000a, 137-38; see also Glasenapp 1942/1915, 57). These agglutinated beings are very small, and their life spans are extremely short, as they do not have the ability to fully develop their bodily capacities (aparyāpta) (GJK 92). Unlike other human beings, they do not even have a mind (Wiley 20ooa, 136-41). Understood in this way, the category of humans born by agglutination has ethical significance for the understanding of sexual union, masturbation, and menstruation, as well as the practice of medicine, given that substances such as blood, mucus, vomit, bile, pus, and other matter all potentially contain minute kinds of agglutinated human beings. For example, an idea emerged that nine hundred thousand living beings are killed during sexual intercourse, most likely referring to the type of living beings discussed here (see chapter 5). Wiley is skeptical, however, about the violability of these beings, pointing out that "if one accepts the view that the life span of these beings is always the minimum possible, then it cannot be cut short by any action whatsoever" (2000a, 139). She continues:

Perhaps a possible explanation for "killing" here might be that of causing harm (himsā) by providing a medium in which these sammūrcchima humans can take birth, whether it be in the body of a woman following intercourse or in other unclean substances mentioned above. By providing a place for their birth, a person would cause massive numbers of these beings to suffer on account of the inevitable rise of asātā-vedanìya-karma and to suffer the pain and fear that are associated with their nearly simultaneous death. $(140)^{92}$

Five-sensed beings that are not born by agglutination are born by the womb and are the result of a sex act between a woman and a man. ${ }^{93}$ Unlike those born through agglutination, five-sensed beings born by the womb have a mind. The Tattvärthasūtra divides womb-born animals into viviparous with placenta (jarāyu), viviparous without placenta (potaja), and oviparous (andaja), meaning those born from an egg (TS $\left.{ }^{\text {ig }} 2.33^{94}\right)$. Humans belong to the viviparous with placenta class, and their new embryonic form is developed in the womb as a combination of nonliving matter from their parents (semen and blood) and their own jiva (to be discussed further in chapter 5 , on reproductive ethics). While ordinary human beings are usually born in a womb that is shaped like a bamboo leaf (vamśapatra-yoni), texts claim that Jinas are born in a tortoise-shaped womb (kūrmonnata-yoni), signifying their special status (GJK 81-82; Wiley 2000a, 221).

\section{The Vitalities, Capacities, and Instincts of Life}

In the beginning of this chapter, we noted that in the Jain tradition, consciousness is the mark by which living stuff is distinguished from nonliving stuff. Jain 
texts also propose another set of criteria by which to recognize life in matter, that is, through the so-called vitalities or life-forces (prāna). Ten vitalities are listed, including (1-5) five sense vitalities (indriya-prāna), (6) vitality of respiration (ucchvāsa-prāna or ānapāna-prāna), (7) vitality of life span (āyu-prāna), ${ }^{95}$ and (8-10) strength vitalities (bala-prāna) of body, speech, and mind (GJK 130; Glasenapp 1999/1925, 198-99). Nemicandra states that only beings that are capable of attaining complete development have the vitality of respiration, and only beings possessing two or more senses have the vitality of speech. Moreover, five-sensed beings with a mind possess the mind vitality. All living beings, both those capable and those incapable of attaining complete development, possess the life span vitality, the vitality of the body (referring to bodily strength or energy), and at least one sense vitality (GJK 132; Wiley 2000a, 188). ${ }^{96}$ This includes human beings who do not have the capacity to fully develop their bodies.

This indicates that vitalities are closely connected with the capacities of the physical body for attaining complete development (paryāpti), which were mentioned above. ${ }^{97}$ There are six such capacities: (1) āhāra-paryāpti (capacity for assimilating matter that builds the body), (2) śarìra-paryāpti (capacity of accumulated matter to form into the body's essential parts), ${ }^{98}$ (3) indriya-paryāpti (capacity for developing the senses), (4) prānāpāna or ucchvāsa-paryāpti (capacity for developing the faculty of respiration), (5) bhāsāa-paryāpti (capacity for developing the faculty of speech), and (6) mano-paryāpti (capacity for developing the mind). One-sensed beings that are capable of development (paryāpta) possess the first four paryāptis, and all living beings with more than one sense possess the additional capacity of speech, and the five-sensed animals and humans with a mind also possess the capacity of mind (GJK 119). While vitalities (prānas) and capacities for attaining complete development (paryāptis) seem to closely resemble one another, Jain texts do distinguish between them. In his comment on the Gommațasāra-jīva-kānda 129, J.L. Jaini explains the difference between them in the following way: "Paryāpti is the attainment of the capacity of developing body, mind, speech, and the five senses, while prāna is the activity of those functionaries" (GJK 90; Wiley 2000a, 187).

Instincts (samjñ $\bar{a})$ are another defining feature of all living beings. They include craving for food (āhāra-samjiñ $\bar{a})$, fear (bhaya-samjiña $)$, desire for reproduction (maithuna-samijñā), and accumulation of things for future use (parigraha-samjiñ $\bar{a}$ ) (GJK 134-38; Jaini 2010e, 284). Among these, craving for food is the root instinct. It should be noted that living beings possessing a mouth consume food voluntarily, whereas those without a mouth absorb food through the surface of their whole bodies involuntarily (Wiley 2002, 42). For example, in the case of womb-born living beings, a jiva entering the womb is said to consume the father's semen, the menstrual blood of the mother, as well as various other liquids (Wiley 2000a, 191; see chapter 5). Because its body is not fully developed, it cannot use its mouth to take food, but rather absorbs it through the entire body. We will address the 
significance of the food instinct in several later chapters, with special attention in chapter 6. The instinct for reproduction will be discussed further in chapter 5 .

\section{Phases of Aging}

The aging process of an embodied being is not explicitly dealt with in Jain texts. Rather, texts describe the decline of bodily strength, the weakening of sensefaculties, and symptoms of deterioration, such as trembling or cough. The Sthānànga-sūtra ${ }^{99}$ describes these processes within ten stages (avasthā) of human life, corresponding to one hundred possible years of existence:

(1) 1-10 years: the stage of a child (bāla)

(2) 10-20 years: the stage of play $(k r i \bar{d} \bar{a})$

(3) 20-30 years: the stage of being slow in understanding or enjoying pleasures (manda)

(4) 30-40 years: the stage of strength (bala)

(5) 40-50 years: the stage of knowledge (prajĩ $\bar{a})$

(6) 50-60 years: the stage of the weakening of the senses (häpana)

(7) 60-70 years: the stage of developing trembling and cough (prapañca)

(8) 70-80 years: the stage of walking with a stoop (prāgbhāra)

(9) 8o-90 years: the stage of wishing for liberation or the end of life (unmukha)

(10) 90-100 years: the stage of lying down (śayana) (SthS 10.154) $)^{100}$

In line with this, a human body will start weakening from the age of fifty onward.

Illness will be described in more detail in later chapters, but it is important to note here that not all humans in the Jain cosmos age and suffer from illness in the same way. Humans who live in the so-called "lands of action" (karma-bhumi), which is also our geographically bound part of the cosmos, do undergo stages of decline. However, humans who live in the so-called "lands of enjoyment" (bhogabhumi) never undergo the physical decline described above and they all die a natural death (on which more below). All wishes and needs are fulfilled without any effort by wishing-trees in the "lands of enjoyment," and suffering is hardly present there. Consequently, liberation is not attainable in those lands, since people are unmotivated to pursue the path of purification, and Jinas are not born there to spread the Jain teaching. On the other hand, living beings must always strive to survive in the "lands of action." Since suffering abounds, they are motivated to seek the path to liberation, which is attainable in these parts of the cosmos, and Jinas are born in these lands to teach the Jain doctrine.

\section{Death and Its Causes}

Just as birth is a beginning of one particular embodied existence rather than the beginning of life itself, Jains "regard death as a transition, not a finality" (Chapple 2010, 189). Life in the form of jiva is indestructible, with only its embodied forms being finite. As indicated in the section on karma, the life duration of an 
embodied living being is determined by a type of nondestructive karma, called longevity-determining karma (âyu-karman). This karma arises prior to death and determines the duration of the next bodily form. As long as the previously bound longevity-determining karma is active, the living being's life continues. The extinguishment of longevity-determining karma marks the death of the living being. This means that the time between the first activation of longevitydetermining karma and its cessation represents the life span of an individual embodied living being. Life spans of embodied beings vary greatly, as we described above regarding the longevity of plant-bodied, earth-bodied, water-bodied, firebodied, and air-bodied beings. Humans born in our current part of the cosmos, whose life spans extend approximately one hundred years, exemplify a duration of life measured in countable numbers (samkhyatta). Some humans who live in the "lands of enjoyment," however, are said to live so long that their life spans are measured in uncountable numbers (asaṃkhyāta) (Wiley 20ooa, 48).

These numbers all represent the ideal amount of time that a living being can exist if nothing intervenes. In other words, if a living being were to die "naturally," it can live up to the full amount of years that are ascribed to it. As we will discuss in chapter 7, a "natural," uninterrupted death is considered to be a timely death (kāla-mrtyu). Those humans residing in the "lands of enjoyment," whose life span is measured in uncountable years, always die "naturally." However, in our part of the cosmos, life can be terminated early due to external efficient causes (nimi$t t a$ ), such as weapons, poison, illness, natural disasters, and accidents. Digambaras also articulate one efficient cause that pertains to death as a result of self-injury or accident, known as upaghāta-nāma-karman, a subclass of nāma-karman. While Śvetāmbaras do not associate this type of karma with death, Digambaras assert that it motivates people to hurt themselves and provides an object or substance that can harm them, such as a poison or weapon (Wiley 2000a, 171-72). This kind of karma, according to Glasenapp, also "produces that the parts of the body of a being (e.g., the uvula in the throat) cause its death" $(1942 / 1915,17)$.

In the case of living beings whose longevity-determining karma is bound very firmly, even the operation of an external efficient cause will not bring about premature death. This is especially true for Jinas, who are described in Jain stories as surviving all manner of mortal attacks and injuries that would typically kill an ordinary person. Ordinary human beings, whose longevity-determining karma is bound loosely, more easily succumb to external efficient causes, and so their lives may result in premature or untimely death (Wiley 2000a, 49-51; see chapter 7). When a living being dies prematurely, all the remaining longevity-determining karma is experienced simultaneously.

Jains place great value on one's mental attitude and conduct in the face of death, be it timely or untimely, which plays a significant role in the Jain ethics of dying. We will explore this more fully in chapter 7 . 


\section{Mechanisms of Rebirth}

As indicated above, jīvas have always been trapped in samsāra, and, as Pūjyapāda explains, the cycle of continued births (bhava-antara) is sustained because of the fruition of karmas (karma-vipāka-vaśa) (SSi 9.7\$801). The type of karma that supports the migration of the jivva from one form of embodied existence to the next is name-determining karma. Glasenapp explains that a specific type of namedetermining karma, called the ànupürvi-näma-karman, "causes that the jīva, when one existence is finished, goes from the place of death in the proper direction to the place of his [sic] new birth" (1942/1915, 16; see also Wiley 2000a, 160). This karma has four subtypes in accordance with the four birth states that it can lead the jivva to.

The aforementioned subtle bodies (karmic body and luminous body) enable jivas to easily and nearly instantaneously pass from one type of principal physical body to the next. These subtle bodies function as a protective vehicle of sorts during the transition. "At the moment of death, the aghätiȳ [nondestructive] karmas have preprogrammed, as it were, the particular conditions of the coming embodiment," says Jaini $(2001 / 1979,126)$. “This information is carried in the kārmana-śarìra [karmic body], which, together with the taijasa-śarìra [luminous body], houses the soul as it leaves its physical body" (126). The nature of jivas themselves is not affected in these transitions. Because they extend in space, jivas can adapt to the size of all the bodies that they occupy and are therefore coextensive with them (sva-deha-parimanna) (DS 2). ${ }^{101}$ Other than that, the Jain doctrine does not offer much more detail about the transitions between various embodiments. Jaini says that, for example, "Jaina texts make absolutely no mention whatsoever of how a soul actually enters the body of the mother-to-be" (2010b, 124; cf. Wiley 2000a, 162-63). This lack of detail is perhaps owing to the fact that transitions occur so quickly. As indicated above, Jain texts are committed to the idea that the transition (antar-gati or vigraha-gati) happens in a single moment, so long as there is a direct line between the previous and the current life. If the jiva needs to make turns to reach its destination, the travel takes a few additional moments (Wiley 2000a, 154-56). Such a fast transition results from the fact that jivas possess an innate ability to move upwards at great speed, though when embodied, this upward movement is corrupted in various ways, causing jīvas to move in different directions. The Tattvārtha-bhāsya explains that "worldly beings (samsārin), owing to the ties of karman, [move] downwards, sidewards, and upwards" (TBh 10.6). It is only in the disembodied state of liberation that this innate upward movement can be completely manifested. According to the Tattvärtha-bhāṣya, "one who is liberated from ties (sainga-vinirmukta) has the motion of one being liberated (sidhyamāna-gati), which is upwards, owing to the upward gravitation (ürdhva-gaurava)" (TBh 10.6). We will look at the state of liberation in the next section. 


\section{Characteristics of Liberation}

The ultimate Jain goal of liberation is also linked to the karma doctrine. We explained above that nondestructive karmic matter determines the jiv $a$ 's body and birth state, but not its inherent qualities. Consequently, a jiva may perfect all of its qualities - such as perception, knowledge, energy, and bliss - while still embodied. Only a human jiva is capable of achieving that, which differentiates it from the rest of embodied beings. As noted, the perfection of consciousness is often described as the perfect knowledge of all existing substances with all of their modes, but has alternatively also been interpreted as the perfect knowledge of the self (Jaini 2001/1979, 266-67; NSã 158). Once the embodied jīva attains perfection, it has fulfilled the necessary condition of attaining liberation and will exit the cycle of rebirths upon death. This means that the body the jiva occupies when it reaches perfection is its final body. ${ }^{102}$ It is important to emphasize that the jiv va does remain in its body even after reaching perfection until its current embodied form ceasesthat is, until all the nondestructive karmas determining its body, longevity, status, and feeling run their natural course and expire (Dundas 2002, 104). ${ }^{103}$ This "exhaustion of all karma is liberation" (TS ${ }^{\text {Dig }} 10.2 ;^{104}$ see also TBh 10.3). Although a human being that has attained perfect knowledge (kevalin) stays in the cycle of rebirths until death and continues to occupy a material body due to the operation of the remaining nondestructive karmic matter that determines its embodiment, its inherent qualities remain perfectly functional until and throughout liberation.

Uniquely, the disembodied liberated being can be viewed as both free from yet still connected to its previous karmically determined body. It is free insofar as the elimination of all karma results in the jīva moving, in a single moment, "upwards to the border of the cosmic space (loka-anta)" (TS 10.5), which is an invertedumbrella-shaped part of the cosmos where liberated jivas remain. ${ }^{105} \mathrm{~A}$ classical Jain example compares this event of the jiva's transformation from bondage to liberation to a gourd that sinks in water when covered with clay, but floats to its surface as soon as the clay is removed (TBh 10.6). Just as the gourd rises when freed from the clay weighing it down, so liberated jiv vas, which have been detached from their bodies and the heavy entanglement with karmic matter, move upwards because that is their natural direction. Once they reach the very top of the cosmos, they stay there forever, never again to be tainted by karmic matter and completely out of reach for jiv vas that remain embodied and trapped in the cycle of rebirths.

At the same time, these bodiless jivas remain connected to their karmic life through the "shape" of their liberated, nonbodied existence. Since the Jain teaching asserts that liberation is only possible from the human birth state, as noted above, the visual image of the liberated jiva, called the siddha, depicts an outline of a hollowed-out, nongendered human form, highlighting its immateriality (Dundas 2002, 105; figure 2). Siddhas are said to retain the size and shape of the body they occupied at the moment of liberation, or rather two-thirds of it (Schubring 


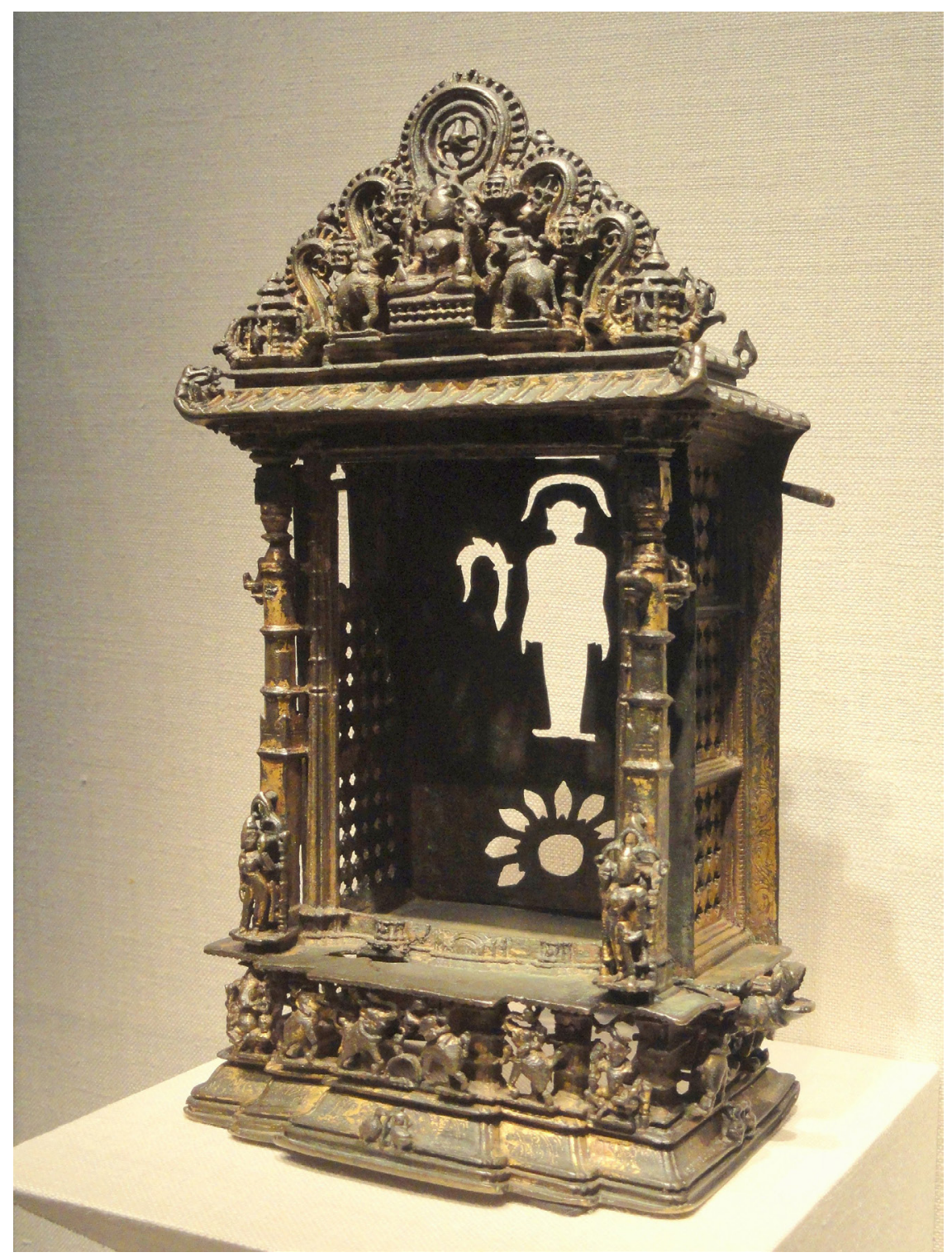

FIGURE 2. This fourteenth-century bronze shrine depicts the outline of the liberated siddha. Credit: Freer Gallery of Art. 
2000/1962, 329; SSi 10.4; Jaini 2010b, 122). ${ }^{106}$ This hollow shape, without flesh or organs, echoes the materiality of its last body even as it is no longer limited by embodied form and function (Donaldson 2015, 79).

It is important to note that liberation is at present not actually possible in our part of the cosmos. Jain cosmology asserts that our specific "land of action" undergoes cycles of time in which conditions improve and decline. Our part of the cosmos has entered a time of general decline (avasarpinin) after the death of Mahāvīra, and no Jinas will be born here until the conditions eventually improve again (utsarpini $\bar{\imath}$. However, there are other "lands of action" that do not undergo these cycles of time where liberation is always possible and Jinas always teach their doctrine. A rebirth there as a human being would represent a possibility of attaining liberation. This means that liberation-and the characteristics of the siddhaoffer a theoretical rather than a practical ideal for the present life of all humans in our part of the cosmos, even among contemporary Jains themselves. Nevertheless, regardless of the geographical context, living beings can still strive toward the perfected qualities exemplified by the siddha, as well as toward other "penultimate goods" (Long 2009, 112). It is the ideal of the siddha-this possibility activated gradually and in penultimate ways - that guides the actions of Jains, encouraging vigilance in a world full of embodied living beings that are easily harmed.

\section{JAIN FOUNDATIONAL PRINCIPLES OF WHAT EXISTS}

Jain authors have propounded a truly complex metaphysical doctrine that defines in great detail the difference between that which is living and that which is not, the violable and nonviolable, and further explains the karmic mechanisms for embodied encounters that so often result in the violation of life. In this section, we identity four key principles related to the Jain account of what exists.

First, life and nonlife are distinct, but entangled, phenomena, in the realm of living beings. To fully understand the structure and dynamics of a living being, one must decipher how life and nonlife entwine within embodied existence.

Second, karma is a material substance that results from the activities of the body, speech, and mind among all living beings. It determines the embodied forms of life and their cognitive capacities, as well as the characteristics of birth, life, aging, death, and rebirth.

Third, living beings are classified in numerous ways-as bound or liberated, according to birth state, by type of body, as individual or communal, by their experience of pain, by sentience, mobility, vitalities, capacities for development, and instincts-but all possess a jīva, characterized by the qualities of consciousness, energy, and bliss. Where life is more difficult to distinguish from the nonliving matter or its nonliving previous material body, it is even more vulnerable to injury.

Fourth, even after liberation, a liberated jīva, or siddha, remains associated with its bodily existence in bearing the physical outline of its final embodied form. 
The ultimate goal of liberation, though seeming to transcend the realm of karmic bondage and its resultant embodiment, remains an expression of both.

The technical details of these principles inform the wider approach to Jain ethics and, thus, provide an essential foundation for considering or developing a Jain approach to modern bioethics. The Jain account of life, nonlife, and karmic causality is presented with an almost mathematical precision. As any such system permits, Jainism allows one to no longer generate causes that result in predictable effects, if the latter become undesirable. 